\title{
No Evidence of Disease at Follow-Up
}

National Cancer Institute

\section{Source}

National Cancer Institute. No Evidence of Disease at Follow-Up. NCI Thesaurus. Code C158755.

No evidence of disease at the follow-up assessment. 